\title{
Risk Factors of Hypertension among Women in Sragen, Central Java
}

\author{
Sudaryanto'), Setyo Sri Rahardjo²), Dono Indarto3) \\ ${ }^{1)}$ Masters Program in Public Health, Universitas Sebelas Maret \\ 2)Department of Pharmacology, Faculty of Medicine, Universitas Sebelas Maret \\ 3)Department of Physiology, Faculty of Medicine, Universitas Sebelas Maret
}

\begin{abstract}
Background: Hypertension has become a global problem because its prevalence continues to increase to the stage of worrying. Health profile data of Sragen District Health Office in 2014 showed that out of 175,750 people aged $>18$ years who took blood pressure measurement, there were $28.73 \%$ (50,499 people) identified as having high blood pressure and 25,928 of them were women. This study aimed to examine risk factors of hypertension among women in Sragen, Central Java, Indonesia.

Subjects and Method: This was a case control study conducted in Sragen, Central Java. The total sample of 200 women was selected by fixed disease sampling. The dependent variable was hypertension. The independent variables were age, history of hypertension, stress, smoking, physical activity, alcohol consumption, salt consumption, coffee consumption, body mass index (BMI), and cholesterol level. Blood pressure was measured by sphygmomanometer. The other data were measured by questionnaire. The data were analyzed by a multiple logistic regression.

Results: Age $\geq 40$ years ( $\mathrm{OR}=5.27 ; 95 \% \mathrm{CI}=1.81$ to $15.28 ; \mathrm{p}=0.002)$, had history of hypertension $(\mathrm{OR}=4.75 ; 95 \% \mathrm{CI}=1.46$ to $15.39 ; \mathrm{p}=0.009)$, stress $(\mathrm{OR}=5.32 ; 95 \% \mathrm{CI}=1.50$ to $18.84 ; \mathrm{p}=0.009)$, smoking $(\mathrm{OR}=17.51 ; 95 \% \mathrm{CI}=1.18$ to $258.70 ; \mathrm{p}=0.037)$, low physical activity $(\mathrm{OR}=7.89 ; 95 \% \mathrm{CI}=$ 2.44 to $25.51 ; \mathrm{p}=0.001)$, alcohol consumption $(\mathrm{OR}=23.06 ; 95 \% \mathrm{CI}=1.49$ to $335.39 ; \mathrm{p}=0.025)$, salt consumption $(\mathrm{OR}=16.68 ; 95 \% \mathrm{CI}=1.61$ to $172.83 ; \mathrm{p}=0.018)$, coffee consumption $(\mathrm{OR}=4.19$; $95 \% \mathrm{CI}=1.03$ to $16.98 ; \mathrm{p}=0.045)$, $\mathrm{BMI}(\mathrm{OR}=5.60 ; 95 \% \mathrm{CI}=1.23$ to $9.71 ; \mathrm{p}=0.018)$, high total cholesterol $(\mathrm{OR}=6.49 ; 95 \% \mathrm{CI}=2.00$ to $21.05 ; \mathrm{p}=0.002)$ increased the risk of hypertension among women. Nagelkerke R Square $=72.2 \%$.

Conclusion: Age $\geq 40$ years, history of hypertension, stress, smoking, low physical activity, alcohol consumption, salt consumption, coffee consumption, BMI, high total cholesterol increase the risk of hypertension among women.
\end{abstract}

Keyword: hypertension, determinants, women

Correspondence:

Sudaryanto. Masters Program in Public Health, Universitas Sebelas Maret. Jl. Ir. Sutami 36 A, Surakarta, Central Java 57126, Indonesia. Email: oment8147@gmail.com.

Mobile: +6285727565551

\section{BACKGROUND}

One in five of the world's population experiences hypertension and half of them die from its complications. As a result of complications of the disease resulted in the death of 9.4 million each year. In countries with high income deaths due to hypertension and its complications, there has been a decline, but in countries with relati- vely low incomes hypertension is growing and tends to increase (WHO, 2015).

According to the Directorate of Prevention and Control of Non-communicable Diseases of the Ministry of Health of Indonesia, in 2016, the prevalence of hypertension in Indonesia is increasing. 2016 hypertension National Health Indicator Survey Report (Sirkesnas) population 
aged $\geq 18$ years consisted of $32.4 \%$. The proportion of new cases of PTM in Central Java in 2016 put hypertension in the first place compared to other non-communicable diseases. Hypertension still occupies the largest proportion of all PTM reported, amounting to 96,968 people (Central Java Provincial Health Office, 2016).

In Sragen, the prevalence of hypertension is high and ranks the first compared to other diseases Sragen Regency in 2014 out of 175,750 people aged $>18$ years who checked blood pressure, $28.73 \%$ of them (50.499 people) were identified as hypertension and 25. 928 of them were women (Health Office of Sragen District, 2014).

This study aimed to examine risk factors of hypertension among women in Sragen, Central Java, Indonesia.

\section{SUBJECTS AND METHOD}

\section{Study Design}

This was a case control study conducted in Sragen, Central Java, from September 25 to November 25, 2018.

\section{Population and Samples}

The population study was women aged 17 to 65 years in Sragen. The total number of 200 women was selected for this study by fixed disease sampling.

\section{Study Variables}

The dependent variable was hypertension. The independent variables were age, history of hypertension, stress, smoking, physical activity, alcohol consumption, salt consumption, coffee consumption, BMI, and cholesterol.

\section{Operational Definition of Variables}

Hypertension was defined as systolic blood pressure $\geq 140 \mathrm{mmHg}$ and diastolic blood pressure $\geq 90 \mathrm{mmHg}$ ) measured in arteries in condition of adequate rest. The measurement scale was continuous, transformed into dichotomous, coded o for ho hypertension and 1 for hypertension.

Age was defined as the difference between the years at the time of the study and the year of birth based on the identity card. The measurement scale was continuous, transformed into dichotomous, coded o for $\leq 45$ years and 1 for $>45$ years.

Hypertension was defined as a history of hypertension that has been suffered both or one of parents. The measurement scale was categorical, coded o for no and 1 for yes.

BMI was defined as a simple assessment to monitor the nutritional status of adults, especially those related to underweight and excess weight which was calculated as weight in kilograms divided by the square of the height in meters $\left(\mathrm{kg} / \mathrm{m}^{2}\right)$. The measurement scale was continous, transformed into dichotomous, coded $\mathrm{o}$ for $\leq 24.9$ and 1 for $>24.9$.

Stress was defined as a physical, psychological tension that a person experiences. The measurement scale was continuous, transformed into dichotomous, coded o for low (score $\leq 14$ ) and 1 for high (score $>14$ ).

Smoking was defined as smoking cigarettes habit everyday in the past month. The scale of the data was categorical, coded o for no smoking and 1 for smoking.

Physical activity was defined as physical exercise carried out for health purposes carried out at least 3 times a week 30 minutes duration. The measurement scale was continuous, transformed into dichotomous, coded o for high physical activity ( $\geq 3$ times/week at least 30 minutes) and 1 for low physical activity $(<3$ times/week with $<30$ minutes).

Alcohol consumption was defined as the frequency of daily alcohol consumption in the past month. The measurement scale 
was categorical, coded o for no and 1 as yes (alcohol consumption $\geq 1$ times a month).

Salt consumption was defined as a daily salt consumption habit in $\mathrm{mg}$. The measurement scale was dichotomous, coded $\mathrm{o}$ for $\leq 2,000 \mathrm{mg}$ and 1 for $>2,000$ mg.

Coffee consumption was defined as the amount of coffee taken or consumed in a day with a cup. The measurement scale was dichotomous, coded o for $\leq 250 \mathrm{ml}(\leq 3$ cups/day) and 1 for $>250 \mathrm{ml}(>3$ cups/ day).

Cholesterol was defined as total cholesterol in the blood as measured by a digital cholesterol measuring device. The measurement scale was continuous, transformed into dichotomous, coded o for $\leq \mathbf{2 0 0}$ $\mathrm{mg} / \mathrm{dl}$ and 1 for $>200 \mathrm{mg} / \mathrm{dl}$.

\section{Data Analysis}

Data analysis techniques used were univariate, bivariate, and multivariate analysis. Univariate analysis aimed to explain each variables. Bivariate analysis aimed to analyze the relationship of independent to dependent variable. Multivariate analysis was performed by a multiple logistic regression.

\section{Research Ethics}

The research ethics included the informed consent, anonymity, confidentiality, and ethical clearance that have been obtained from Research Ethics Committee, Faculty of Medicine, Universitas Sebelas Maret, Surakarta, Central Java, with No. 275/UN27.6/ KEPK / 2018.

\section{RESULTS \\ 1. Univariate Analysis}

Table 1 shows that as many as 68 women had normal systolic blood pressure, 75 women had pre-hypertension in diastolic blood pressure. As many as 136 women (68\%) had normal BMI. As many as 139 women (69.5\%) had normal total cholesterol. As many as 151 women (75.5\%) did not have history of hypertension. As many as 103 women had high physical activity.

\section{Bivariate Analysis}

Table 2 showed the results of bivariate analysis. Table 2 showed that total cholesterol was associated with hypertension $(\mathrm{OR}=6.56 ; \mathrm{p}<0.001)$. High total cholesterol increased the risk of hypertension among women.

BMI was associated with hypertension $(\mathrm{OR}=4.55 ; \mathrm{p}<0.001) . \quad \mathrm{BMI} \geq 25$ increased the risk of hypertension among women.

History of hypertension was associated with hypertension $(\mathrm{OR}=8.10 ; \mathrm{p}$ $<0.001)$. Women who had history of hypertension increased the risk of hypertension.

Age was associated with hypertension $(\mathrm{OR}=4.94 ; \mathrm{p}<0.001)$. Age $\geq 45$ years increased the risk of hypertension.

Smoking was associated with hypertension $(\mathrm{OR}=25.92 ; \mathrm{p}<0.001)$. Women smoker increased the risk of hypertension.

Physical exercise was associated with hypertension $(\mathrm{OR}=4.06 ; \mathrm{p}<0.001)$. Low physical activity increased the risk of hypertension.

Alcohol consumption was associated with hypertension $(\mathrm{OR}=10.64 ; \mathrm{p}=0.009)$. Alcohol consumption increased the risk of hypertension.

Coffee consumption was associated with hypertension ( $\mathrm{OR}=2.89 ; \mathrm{p}=0.005)$. Coffee consumption increased the risk of hypertension.

Stress was associated with hypertension $(\mathrm{OR}=13.21 ; \mathrm{p}<0.001)$. Stress increased the risk of hypertension.

Salt consumption was associated with hypertension $(\mathrm{OR}=22.27 ; \mathrm{p}<0.001)$. Salt consumption $>2000 \mathrm{mg} /$ day increased the risk of hypertension. 
Journal of Epidemiology and Public Health (2019), 4(2): 127-137

https://doi.org/10.26911/jepublichealth.2019.04.02.08

Table 1. Univariate Analysis

\begin{tabular}{|c|c|c|}
\hline Characteristics & (n) & (\%) \\
\hline \multicolumn{3}{|l|}{ Systolic blood pressure } \\
\hline Normal & 68 & 34 \\
\hline Pre Hypertension & 69 & 34.5 \\
\hline Hypertension & 63 & 31.5 \\
\hline \multicolumn{3}{|l|}{ Diastolic blood pressure } \\
\hline Normal & 61 & 30.5 \\
\hline Pre hypertension & 75 & 37.5 \\
\hline Hypertension & 64 & 32 \\
\hline \multicolumn{3}{|l|}{ BMI $\left(\mathrm{kg} / \mathbf{m}^{2}\right)$} \\
\hline Underweight & 3 & 1.5 \\
\hline Normal & 136 & 68 \\
\hline Overweight & 55 & 27.5 \\
\hline Obese & 6 & 3 \\
\hline \multicolumn{3}{|l|}{ Total cholesterol (mg/dl) } \\
\hline Normal & 139 & 69.5 \\
\hline High threshold & 39 & 19.5 \\
\hline High & 22 & 11 \\
\hline \multicolumn{3}{|l|}{ History of Hypertension } \\
\hline No & 151 & $75 \cdot 5$ \\
\hline Yes & 49 & 24.5 \\
\hline \multicolumn{3}{|l|}{ Age } \\
\hline Late teenagers & 15 & 7.5 \\
\hline Early adults & 24 & 12 \\
\hline Late adults & 70 & 35 \\
\hline Early elderly & 77 & 38.5 \\
\hline Late elderly & 14 & 7 \\
\hline \multicolumn{3}{|l|}{ Smoking } \\
\hline No smoking & 188 & 94 \\
\hline Mild smoker & 12 & 6 \\
\hline \multicolumn{3}{|l|}{ Physical Activity } \\
\hline Yes & 103 & 51.5 \\
\hline \multirow{2}{*}{\multicolumn{3}{|c|}{ Duration }} \\
\hline & & \\
\hline Not at all & 103 & 51.5 \\
\hline$\geq 30$ minutes & 73 & 36.5 \\
\hline$<30$ minutes & 24 & 12 \\
\hline \multicolumn{3}{|l|}{ Frequency of physical activity } \\
\hline No & 103 & 51.5 \\
\hline$\geq 3$ times/week & 16 & 8 \\
\hline$<3$ times/week & 80 & 40 \\
\hline \multicolumn{3}{|l|}{ Alcohol Consumption } \\
\hline Not consuming & 194 & 97 \\
\hline Occasional drinker ( $\leq 3$ times/ month) & 1 & 0.5 \\
\hline Frequent drinker (4 times/month) & 1 & 0.5 \\
\hline Regular drinker ( $>4$ times/month & 4 & 2 \\
\hline \multicolumn{3}{|l|}{ Coffee Consumption } \\
\hline$\leq 250 \mathrm{ml}(3$ cups a day $)$ & 167 & 83.5 \\
\hline$>250 \mathrm{ml}$ (>3 cups a day) & 33 & 16.5 \\
\hline \multicolumn{3}{|l|}{ Stress Category } \\
\hline Normal & 155 & 77.5 \\
\hline Mild & 25 & 12.5 \\
\hline Moderate & 9 & 4.5 \\
\hline Severe & 5 & 2.5 \\
\hline & 6 & 3 \\
\hline \multicolumn{3}{|l|}{ Salt Consumption } \\
\hline$\leq 2000 \mathrm{mg}$ & 181 & 90.5 \\
\hline$>2000 \mathrm{mg}$ & 19 & 9.5 \\
\hline
\end{tabular}


Table 2. Bivariate Analysis

\begin{tabular}{|c|c|c|c|c|c|c|}
\hline \multirow{3}{*}{ Independent Variables } & \multicolumn{4}{|c|}{ Hypertension Status } & \multirow{3}{*}{$\mathbf{O R}$} & \multirow{3}{*}{$\mathbf{p}$} \\
\hline & \multicolumn{2}{|c|}{ No } & \multicolumn{2}{|c|}{ Yes } & & \\
\hline & $\mathbf{N}$ & $\%$ & $\mathbf{N}$ & $\%$ & & \\
\hline \multicolumn{7}{|l|}{ Body Mass Index } \\
\hline - $\quad \leq 24.9 \mathrm{~kg} / \mathrm{m}^{2}$ & 106 & $77 \cdot 4$ & 31 & 22.6 & 4.55 & $<0.001$ \\
\hline - $\quad>24.9 \mathrm{~kg} / \mathrm{m}^{2}$ & 27 & 42.9 & 36 & 57.1 & & \\
\hline \multicolumn{7}{|l|}{ Total Cholesterol } \\
\hline - $\leq 200 \mathrm{mg} / \mathrm{dl}$ & 114 & 78.1 & 32 & 21.9 & 6.56 & $<0.001$ \\
\hline - $\quad>200 \mathrm{mg} / \mathrm{dl}$ & 19 & 35.2 & 35 & 64.8 & & \\
\hline \multicolumn{7}{|l|}{ The history of hypertension } \\
\hline - No history & 118 & 78.1 & 33 & 21.9 & 8.10 & $<0.001$ \\
\hline - With history & 15 & 30.6 & 34 & 69.4 & & \\
\hline \multicolumn{7}{|l|}{ Age } \\
\hline - < 45 years & 88 & 82.2 & 19 & 17.8 & 4.94 & $<0.001$ \\
\hline - $\quad \geq 45$ years & 45 & 48.4 & 48 & 51.6 & & \\
\hline \multicolumn{7}{|l|}{ Smoking status } \\
\hline - No smoking & 132 & 70.2 & 56 & 29.8 & $25 \cdot 92$ & $<0.001$ \\
\hline - Smoking & 1 & 8.3 & 11 & 91.7 & & \\
\hline \multicolumn{7}{|l|}{ Physical Exercise } \\
\hline - $\quad \geq 3 \mathrm{x} /$ week, 30 minutes) & 82 & 81.2 & 19 & 18.8 & 4.06 & $<0.001$ \\
\hline - $\quad<3 x /$ week, $<30$ minutes) & 51 & 51.5 & 48 & 48.5 & & \\
\hline \multicolumn{7}{|l|}{ Alcohol consumption } \\
\hline - Not consuming & 132 & 68.0 & 62 & 32.0 & 10.64 & 0.009 \\
\hline - Consuming ( $\geq 1 \mathrm{x} /$ month) & 1 & 16.7 & 5 & 83.3 & & \\
\hline \multicolumn{7}{|l|}{ Coffee consumption } \\
\hline - $\quad \leq 250 \mathrm{ml}$ (3 cups per day) & 118 & 70.7 & 49 & 29.3 & 2.89 & 0.005 \\
\hline - $\quad>250 \mathrm{ml}$ (>3 cups per day) & 15 & $45 \cdot 5$ & 18 & 54.5 & & \\
\hline \multicolumn{7}{|l|}{ Stress } \\
\hline - $\quad$ No $(\leq 14)$ & 121 & 80.7 & 29 & 19.3 & 13.21 & $<0.001$ \\
\hline - $\quad$ Yes $(>14)$ & 12 & 24.0 & 38 & 76.0 & & \\
\hline \multicolumn{7}{|l|}{ Salt consumption } \\
\hline - $\quad \leq 2000 \mathrm{mg}$ & 131 & 72.4 & 50 & 27.6 & 22.27 & $<0.001$ \\
\hline - $>2000 \mathrm{mg}$ & 2 & 10.5 & 17 & 89.5 & & \\
\hline
\end{tabular}

\section{Multivariate Analysis}

Table 3 showed the results of multivariate analysis by a multiple logistic regression. Table 3 showed that $\mathrm{BMI} \geq 25(\mathrm{OR}=5.60$; $95 \% \mathrm{CI}=1.23$ to $9.71 ; \mathrm{p}=0.018)$, high total cholesterol $\geq 200 \mathrm{mg} / \mathrm{dl}(\mathrm{OR}=6.49 ; 95 \%$ $\mathrm{CI}=2.00$ to $21.05 ; \mathrm{p}=0.002)$, had history of hypertension $(\mathrm{OR}=4.75 ; 95 \% \mathrm{CI}=1.46$ to 15.39; $\mathrm{p}=0.009)$, age $>45$ years old $(\mathrm{OR}=$ $5.27 ; 95 \% \mathrm{CI}=1.81$ to $15.28 ; \mathrm{p}=0.002)$, smoking $(\mathrm{OR}=17.51 ; 95 \% \mathrm{CI}=1.18$ to 258.70; $\mathrm{p}=0.037$ ), low physical exercise $(\mathrm{OR}=7.89 ; 95 \% \mathrm{CI}=2.44$ to $25.51 ; \mathrm{p}=$ o.001), alcohol consumption $(\mathrm{OR}=23.06$; 95\% $\mathrm{CI}=1.49$ to $335.39 ; \mathrm{p}=0.025$ ), high coffee consumption $(\mathrm{OR}=4.19 ; 95 \% \mathrm{CI}=$ 1.03 to $16.98 ; \mathrm{p}=0.045)$, stress $(\mathrm{OR}=5.32$; 95\% CI $=1.50$ to $18.84 ; \mathrm{p}=0.009$ ), and salt consumption $(\mathrm{OR}=16.68$; $95 \% \mathrm{CI}=1.61$ to 172.83; $\mathrm{p}=0.018$ ) increased the risk of hypertension among women.

BMI, total cholesterol, history of hypertension, age, smoking, physical activity, alcohol consumption, coffee consumption, stress, and salt consumption can explain factors associated with hyperten- 
Journal of Epidemiology and Public Health (2019), 4(2): 127-137

https://doi.org/10.26911/jepublichealth.2019.04.02.08

sion among women in Sragen by $72.2 \%$

(Nagelkerke R Square $=72.2 \%)$.

Table 3. The results of multivariate analysis

\begin{tabular}{|c|c|c|c|c|}
\hline \multirow{2}{*}{ Variables } & \multirow{2}{*}{$\mathbf{O R}$} & \multicolumn{2}{|c|}{$95 \%$ CI } & \multirow[b]{2}{*}{$\mathbf{p}$} \\
\hline & & Lower limit & Upper limit & \\
\hline Body mass index (BMI) & 5.60 & 1.23 & 9.71 & 0.018 \\
\hline Total cholesterol & 6.49 & 2.00 & 21.05 & 0.002 \\
\hline History of disease & 4.75 & 1.46 & $15 \cdot 39$ & 0.009 \\
\hline Age & 5.27 & 1.81 & 15.28 & 0.002 \\
\hline Smoking status & 17.51 & 1.18 & 258.70 & 0.037 \\
\hline Physical exercise & 7.89 & 2.44 & 25.51 & 0.001 \\
\hline Alcohol consumption & 23.06 & 1.49 & 355.39 & 0.025 \\
\hline Coffee consumption & 4.19 & 1.03 & 16.98 & 0.045 \\
\hline Stress & $5 \cdot 32$ & 1.50 & 18.84 & 0.009 \\
\hline Salt consumption & 16.68 & 1.61 & 172.83 & 0.018 \\
\hline \multicolumn{5}{|l|}{$\mathrm{N}$ observation $=200$} \\
\hline -2 Log Likelihood & 108.01 & & & \\
\hline Nagelkerke R Square & $72.2 \%$ & & & \\
\hline
\end{tabular}

\section{DISCUSSION}

\section{The effect of BMI on hypertension}

There was a significant effect of BMI on hypertension among women in Sragen. The result of this study was in line with Sumardiyono et al. (2015) who stated that there was a relationship between BMI (obesity) and hypertension. People with obesity were 6 times more likely to have hypertension compared to people who were not obese.

A study of Dua Suman (2014) showed that subjects who have obesity tend to have hypertension than subjects with normal BMI. Rush (2018) stated that there was a significat relationship between BMI and hypertension in Zambia urban area. A study by Kalangie (2016) concluded that there was a significant effect of BMI on blood pressure.

The enhancement of body weight would increase the need for blood to supply oxygen to body tissues. Increased blood volume in the circulation of blood vessels increased blood pressure in the arterial wall (Estiningsih, 2012).

\section{The effect of total cholesterol on hypertension}

The result of analysis showed that total cholesterol affected hypertension. The result of this study supported a study by Ulfah (2017), which stated that there was a significant effect of total cholesterol on blood pressure. Harefa (2017) stated that cholesterol level affected the level of hypertension in the working area of the Hiliweto Gido Health Center, Nias Regency. Otsuka (2016) in his study found that cholesterol levels played a role in influencing blood pressure.

The heart pumped more strongly so that more fluid was flowed every second, large arteries lose their flexibility and become narrower because of the plaque caused by cholesterol in the blood vessel walls. Blood was forced to pass through narrow vessels and it increased the pressure (Triyanto, 2014). Fat deposits blocked the flow of blood through the arteries. Both of these factors tend to increase blood pressure (Wade, 2016).

\section{The effect of history of hyperten- sion on hypertension}

Parental history of hypertension affected hypertension and it was statistically significant.

The result of this study was in line with a study by Heriziana (2017), which stated that there was a relationship 
between family history of hypertension and the incidence of hypertension.

Genetic factors contributed to the occurrence of hypertension around 30-60\% in various individuals (Singh, 2017). Hereditary factors played a role in the occurrence of hypertension compared to environmental factors. The nature of the hypertension gene was dominant. Individual hypertension existed in every generation, and people who did not have history of hypertension would have children who were not hypertensive as well. History of hypertension both from father or mother, can be inherited both to male and female children (Henuhili, 2011).

Genetic factors played a role in high blood pressure, heart disease, and other related conditions. There was a possibility that people with a family history of hypertension could share with the general environment and other potential factors that increase the risk. The risk for high blood pressure could increase even when the heredity joined in unhealthy lifestyle choices, such as smoking and eating unhealthy foods (CDC, 2014).

\section{The effect of age factor on hyper- tension}

There was a relationship between age and hypertension among women. A study of Gerungan (2016) stated that there was a significant relationship between age factor and the incidence of hypertension. Based on the result of data analysis with logistic regression in a study done by Amaliah (2014) in Sulawesi, it showed that risk factors which related to hypertensions were age, gender, employment, and economic status. A study of Heriziana (2017) in Basuki Rahmat Health Center in Palembang showed that there was a relationship between age and the incidence of hypertension.
Increased blood pressure was associated with changes in arterial elasticity. Stiffness of the arteries, especially large arteries was due to structural changes and calcification of arteries. This could increase the blood pressure. The aging process played an important role in increasing blood pressure. Decreasing kidney function as the aging process became an important factor that also influenced blood pressure (Pinto, 2007).

\section{The effect of smoking on hyper- tension}

The result of data analysis showed that there was a significant relationship between smoking and hypertension.

The result of this study supported a study done by Setyanda (2015) with the significance result of $\rho=0,003$, it stated that there was a relationship between smoking habit and hypertension. A study of Eirmawati (2014) in dr. Soebandi Hospital, Jember showed a significant result between smoking and hypertension, and the score of significance was $\rho=0.000$ and Ods Ratio was 6.429. A study done by Leskiv (2015) stated that higher blood pressure was found among active smokers than passive smokers. To enable better blood pressure control, people should regularly got counseling about smoking and its impact on blood pressure.

Cigarettes contain harmful substances to the body. Smoking has an effect on the increase in blood pressure because basically, CO (carbon monoxide) content can lead to spasm (shrinking) of blood vessels resulting in increased blood pressure (Tawbariah, 2014). The content of nicotine caused stimulation of the hormone epinephrine (adrenaline) which stimulated an increase in heart rate. The heart worked harder so that the blood pressure rised and it could lead to hypertension. Other effects of nicotine were stimulating groups of 
Journal of Epidemiology and Public Health (2019), 4(2): 127-137

https://doi.org/10.26911/jepublichealth.2019.04.02.08

platelets (blood clotting cells), platelets would clot and eventually would clog the blood vessels due to smoke which contain CO gas from cigarettes (Tawbariah, 2014). Smoking triggered the occurrence of atherosclerosis/stiffening of the arteries which ultimately triggered an increase in arterial blood pressure. People with hypertension and still smoking would probably develop severe hypertension, including malignant hypertension and renovascular hypertension which ultimately affected kidney problems (Virdis, 2010).

\section{The effect of physical exercise on hypertension}

Physical exercise affected hypertension and it was statistically significant. Low physical exercise ( $<3$ times/week and $<30$ minutes) increased the risk of hypertension.

A study by Rahadiyanti (2013) showed that from 102 samples, 63 study subjects (61.8\%) had controlled blood pressure. This study showed the relationship between exercise habits (walking) with blood pressure control in hypertensive patients $(\mathrm{p}=0.001)$. A study by Putriastuti (2016) showed that there was relationship between exercise habits and hypertension in research subjects aged $>45$ years old. Exercise has an important role and was highly recommended to prevent hypertension. With regular exercise and measured, atherosclerosis can be prevented, reduce blood cholesterol levels and also reduce the risk of hypertension and cardiovascular disease (WHO, 2017).

\section{The effect of alcohol consumption on hypertension}

The results of this study showed that alcohol consumption had a positive effect on hypertension.

A study of Komaling (2013) showed that there was a relationship between alcohol consumption and hypertension $(\mathrm{p}<0.001)$. There was a relationship bet- ween consumption time, type of alcohol, and frequency of consumption with hypertension. A study done by Ruus (2016) showed that there was a relationship between alcohol consumption and hypertension $(\mathrm{p}=0.006)$. A study by Malonda (2012) stated that there was an effect of alcohol on hypertension $(\mathrm{OR}=2.8$; $\mathrm{p}<0.005$ ).

The effect of alcohol consumption was similar to the effects of carbondioxide which made the blood become thicker so that the heart was forced to pump more strongly and ultimately increased the blood pressure. Increased alcohol consumption in the long term affected the increase in blood cortisol levels so that the rennin angiotensin aldosterone system (RAAS) activity was increased, a system of hormones that regulated the balance of blood pressure and fluid in the body. Someone who consumed alcohol would have an enhancement of the volume of red blood cells in the body. This would increase blood viscosity which can increase blood pressure (Komaling, 2013). Counseling to the public regarding factors that can trigger hypertension was needed as well as prevention by limiting alcohol consumption.

\section{The effect of coffee consumption on hypertension}

The results of this study showed that coffee consumption had a positive effect on hypertension. Coffee consumption $>250 \mathrm{ml}$ (> 3 cups/days) increased the risk of hypertension 4.19 times among women.

A study of Kurniawaty (2016), showed that there was an effect of coffee consumption on blood pressure. Drinking excess coffee was dangerous for people with hypertension because caffeine compounds could increase blood pressure. Caffeine in the body took over the adinosin receptor in nerve cells which would trigger the production of adrenaline hormones and increased 
the blood pressure. In addition, caffeine has endogenous adenosine antagonist properties, which could lead to vasoconstriction. People who smoke would also have coffee consumption habit. If both habits were carried out together, it would worsen the condition.

\section{The effect of stress on hyper- tension}

There was a positive effect between stress on hypertension. Liu (2017) showed the relationship between stress and increased risk of hypertension with OR $=2.40$. Spruill (2010) stated that psychosocial stress factors contributed positively to hypertension. Efforts to prevent hypertension need to be done by doing intervention to stress, namely by exercising, mental relaxation (recreation), conveying problems experienced by others, fostering positive emotions, and deepening worship and religion. Periodic blood pressure measurements were needed especially for people who were at risk and screening for hypertension cases by managers of hypertension control programs.

Stress triggered hypertension through activation of the sympathetic nervous system which resulted in intermittent (erratic) blood pressure rise (Andria, 2013). When someone was stressed, the adrenaline hormone would be released and then would increase blood pressure through arterial contraction (vasoconstriction) and increased heart rate. If stress was continued, blood pressure would remain high so that the person would experience hypertension (South, 2014).

\section{The effect of salt consumption on hypertension}

The results of this study showed that salt consumption affected hypertension. Salt consumption $>\mathbf{2 0 0 0 ~} \mathrm{mg}$ /days increased the risk of hypertension 16.68 times.
Rachmawati (2013) stated that excessive salt consumption has an effect on hypertension in young adult study subjects in Pondok Sukoharjo Village. Frisoli (2012) stated that salt intake affected blood pressure, high salt intake could increase not only blood pressure but also other diseases such as stroke. Reducing salt intake was one of the top priority actions to overcome not only hypertension but also the global non-communicable disease crisis. Reducing salt intake in a large population was needed to reduce the number of deaths caused by hypertension, cardiovascular disease, and stroke (Ha, 2014).

\begin{tabular}{l}
\hline REFERENCES \\
\hline Amaliah F, Sudikno (2014). Faktor risiko \\
hipertensi pada orang umur 45-74 \\
tahun di pulau Sulawesi. Gizi Indon. \\
37 (2): 145-151 \\
Andria KM (2013). Hubungan antara peri- \\
laku olahraga, stres dan pola makan \\
dengan tingkat hipertensi pada lanjut \\
usia di posyandu lansia Kelurahan \\
Gebang Putih Kecamatan Sukokilo \\
Kota Surabaya. Jurnal Promkes. 1(2): \\
111-117
\end{tabular}

Centers for disease and prevention (2015). High blood pressure fact sheet. Diakses tanggal o8 Agustus 2018 dari https://www.cdc.gov/dhdsp/data_sta tistics/fact_sheets/fs_bloodpressure. htm

Dinkes Provinsi Jateng (2016). Buku saku kesehatan tahun 2016

Dua S, Bhuker M, Sharma P, Dhall M, Kapoor S (2014). Body mass index relates to blood pressure among adults. North American Journal of Medical Sciences. 6(2): 89-95.

Eirmawati C, Wiratmo, Budi Prihwanto. (2014). Hubungan antara Kebiasaan Merokok dengan Kejadian Hipertensi 
Journal of Epidemiology and Public Health (2019), 4(2): 127-137

https://doi.org/10.26911/jepublichealth.2019.04.02.08

di RSD dr. Soebandi Jember. e-Jurnal

Pustaka Kesehatan. 2 (2): 314-319

Estiningsih H S. (2012). Hubungan indeks massa tubuh dan faktor lain dengan kejadian hipertensi pada kelompok usia 18-44 tahun di Kelurahan Sukamaju Depok tahun 2012. Fakultas Kesehatan Masyarakat. Universitas Indonesia

Frisoli TM, Schmieder RE, Grodzicki T, Messerli FH (2012). Salt and hypertension: is salt dietary reduction worth the effort?. The American Journal of Medicine. 125(5): 433-439

Gerungan AMT, Kalesaran AFC, Akili RH (2016). Hubungan antara umur, aktivitas fisik dan stress dengan kejadian Hipertensi di Puskesmas Kawangkoan. Fakultas Kesehatan Masyarakat. Universitas Sam Ratulangi.

Ha SK (2014). Dietary salt intake and hypertension. US National Library of Medicine National Institutes of Health. 12(1): 7-18.

Harefa MV (2017). Hubungan kadar kolesterol dengan derajat hipertensi Pada penderita hipertensi di wilayah kerja Puskesmas Hiliweto Gido, Kabupaten Nias. Fakultas kesehatan masyarakat. Universitas Sumatera Utara.

Henuhili V, Yuliati, Rahayu T, Nurkhasanah L (2011). Pola pewarisan penyakit hipertensi dalam keluarga sebagai sumber belajar genetika. Pendidikan Biologi FMIPA UNY

Heriziana (2017). Faktor resiko kejadian penyakit hipertensi di Puskesmas Basuki Rahmat Palembang. Jurnal kesmas Jambi. 1 (1): 32-39

Kalangie VM, Warouw SM, Umboh A (2016). Hubungan berat badan dengan tekanan darah pada siswa SMP di Kecamatan Pineleng. Jurnal e-clinic. 4 (1):1-5
Komaling JK, Suba B, Wongkar D (2013). Hubungan mengonsumsi alkohol dengan kejadian hipertensi pada lakilaki di Desa Tompasobaru Kecamatan Tompasobaru Kabupaten Minahasa Selatan. ejurnal keperawatan (e-Kp). 1 (1): $1-7$

Kurniawaty E, Insan ANM (2016). Pengaruh Kopi terhadap Hipertensi. Majority. 5(2): 6-10.

Leskiv I, Povroznyk N, Mulka L, Cherevychnyk N, Dzyaman M (2015). Effect of smoking on blood pressure control in hypertensive men. Journal of Hypertension. 33: 16-11.

Liu M Y, Li N, Li W A, Khan H (2017). Association between psychosocial stress and hypertension: a systematic review and meta-analysis. US National Library of Medicine National Institutes of Health. 39 (6): 573-580

Malonda NSH, Dinarti LK, Pangastuti R (2012). Pola makan dan konsumsi alkohol sebagai faktor risiko hipertensi pada lansia. Jurnal Gizi Klinik Indonesia. 8(4): 202-212.

Martiana A, Wardhana A, Pratiwi PH (2017). Merokok sebagai symbol interaksi bagi perokok perempuan urban. Fakultas Ilmu Sosisologi. UNY.

Otsuka T, Takada H, Nishiyama Y, Kodani E, Saiki Y, Kato K, Kawada T (2016). Dyslipidemia and the risk of developing hypertension in a working-age male population. Journal of the American Heart Association. 5(3):1-9.

Pinto E (2007). Blood pressure and ageing. Postgraduate Medical Journal. 83 (976): 109-114.

Putriastuti L (2016). Analisis hubungan antara kebiasaan olahraga dengan kejadian hipertensi pada pasien usia 45 tahun ke atas. Jurnal Berkala Epidemiologi. 4 (2). 225-236 
Rachmawati YD (2013). Hubungan antara gaya hidup dengan kejadian hipertensi pada usia dewasa muda di Desa pondok Kecamatan Nguter Kabupaten Sukoharjo. Fakultas Ilmu Kesehatan. Universitas Muhammadiyah Surakarta

Rahadiyanti LS (2013). Hubungan kebiasaan berolahraga jalan kaki dengan kontrol tekanan darah pada pasien hipertensi. Fakultas kedokteran dan ilmu kesehatan. Universitas Islam Negeri Syarif Hidayatulah

Rush K L, Goma FM, Barker JA, Ollivier RA, Ferrier M S, Singini D. (2018). Hypertension prevalence and risk factors in rural and urban Zambian adults in western province: a crosssectional study. The pan african journal. 30 (97):1-8

Ruus M, Kepel B J. Umboh J M L. (2016). Hubungan antara konsumsi alkohol dan kopi dengan kejadian hipertensi pada laki-laki di Desa Ongkaw Dua Kecamatan Sinonsayang Kabupaten Minahasa Selatan. Fakultas Kesehatan Masyarakat. Universitas Sam Ratulangi Manado

Setyanda YOG, Sulastri D, Lestari Y (2015). Hubungan merokok dengan kejadian hipertensi pada laki-laki usia 35-65 tahun di Kota Padang. Jurnal Kesehatan Andalas. 4(2): 434-441.

Singh PK, Pandey AK, Rani S (2017). Hypertension and its risk factors- a cross sectional study in rural area. Journal of Evidence Based Medicine and Healthcare. 4(44): 2663-2667.

Spruill TM (2010). Chronic psychosocial stress and hypertension. US National Library of Medicine National Institutes of Health. 12 (1): 10-16.

Sumardiyono, Ada YR, Wijayanti R, Rinawati $S$ (2015). Pengaruh indeks massa tubuh (IMT) terhadap tekanan darah Pada pekerja yang terpapar bising industri di Surakarta. Universitas Muhammadiyah Purwokerto.

Suoth M, Bidjuni H, Malara RT (2014). Hubungan gaya hidup dengan kejadian hipertensi di Puskesmas Kolongan Kecamatan Kalawat Kabupaten Minahasa Utara. Unsrat ejournal. 2(1): 1-10

Tawbariah L (2014). Hubungan konsumsi rokok dengan perubahan tekanan darah pada masyarakat di Pulau Pasaran Kelurahan Kota Karang Kecamatan Teluk Betung Timur Bandar Lampung. Fakultas Kedokteran Universitas Lampung

Triyanto E (2014). Pelayanan keperawatan bagi penderita hipertensi secara terpadu. Yogyakarta: Graha Ilmu.

Ulfah M, Sukandar H, Afiatin (2017). Hubungan kadar kolesterol total dengan tekanan darah pada masyarakat Jatinangor. JSK. 3(2): 58-64.

Virdis A, Giannarelli C, Neves MF, Taddei S, Ghiadoni L (2010). Cigarette smoking and hypertension. US National Library of Medicine National Institutes of Health. 16(23): 2518-25.

Wade C (2016). Mengatasi Hipertensi. Bandung. Nuansa Cendekia

WHO (2015). Q\&As on hypertension. Diakses tanggal 24 November 2017 dari http://www.who.int/features/qa/82/en/

World Health Organization (2017). Physical activity for patients with hypertension: A noncommunicable disease education manual for primary health care professionals and patients. Diakses tanggal 15 Oktober 2018 dari http://iris.wpro.who.int/bitstream/h andle/10665.1/13561/978929061801 o-hyp-mod5-eng.pdf 